\title{
Soil hydrophobicity: comparative study of usual determination methods
}

\author{
Hidrofobicidade do solo: estudo comparativo dos métodos usuais de determinação
}

\author{
Eduardo Saldanha Vogelmann ${ }^{\mathrm{I}}$ José Miguel Reichert ${ }^{\mathrm{II}}$ Juliana Prevedello $^{\mathrm{II}}$ \\ Gabriel Oladele Awe ${ }^{\mathrm{III}}$ Dalvan José Reinert ${ }^{\mathrm{II}}$
}

\section{ABSTRACT}

Hydrophobic or water repellent soils slowly absorb water because of the low wett ability of the soil particles which are coated with hydrophobic organic substances. These pose significant effects on plant growth, water infiltration and retention, surface runoff and erosion. The objective of this study was to compare the performance of tension micro-infiltrometer(TMI) and the water drop penetration time (WDPT) methods in the determination of the hydrophobicity index of eighteen soils from southern Brazil. Soil samples were collected from the $0-5 \mathrm{~cm}$ soil layer to determine particle size distribution, organic matter content, hydrophobicity index of soil aggregates and droplet penetration time of disaggregated and sieved soil samples. For the TMI method the soil samples were subjected to minor changes due to the use of macroaggregates to preserve the distribution of solid constituents in the soil. Due to the homogeneity of the soil samples the WDPT method gave smaller coefficients of variation unlike the TMI method where the soil structure is preserved. However, both methods had low coefficients of variation, and are thus effective for determining the soil hydrophobicity, especially when the $\log$ hydrophobicity index or log WDPT is $>1$.

Key words: water repellency, water drop penetration time, water infiltration.

\section{RESUMO}

Solos hidrofóbicos ou repelentes à água geralmente absorvem-na lentamente, devido à reduzida sortividade proveniente do recobrimento das partículas do solo por substâncias orgânicas hidrofóbicas. A hidrofobicidade do solo é uma propriedade com significativos efeitos no crescimento de plantas, infiltração e retenção de água, escoamento superficial e erosão. $O$ objetivo deste estudo foi comparar o desempenho do método do microinfiltrômetro de tensão (TMI) e do método do tempo de penetração da gota (WDPT) na determinação do índice de hidrofobicidade em dezoito classes de solos do sul do Brasil. Amostras de solo foram coletadas na camada de 0-5cmpara a determinação da distribuição granulométrica, o conteúdo de matéria orgânica, indice de hidrofobicidade em agregados de solo e o tempo de penetração da gota em amostras de solo desagregadas e peneiradas. $O$ método do microinfiltrômetro de tensão as amostras foram submetidas a menores alterações, devido ao uso de macroagregados, preservando a distribuição dos compostos no solo. Em função da homogeneização da amostra de solo, o método do WDPT pode apresentar menores coeficientes de variação, diferentemente do método do microinfiltrômetro em que a estrutura do solo é preservada. Contudo, ambos os métodos apresentaram baixos coeficientes de variação e, portanto, são efetivos na determinação da hidrofobicidade do solo, especialmente quando o $\log$ do indice de hidrofobicidade ou log WDPT é>1.

Palavras-chave: repelência à água, tempo de penetração da gota, infiltração de água.

\section{INTRODUCTION}

Soil hydrophobicity is an environmental problem of soil repellency to water that hampers soil wetting. This is a global phenomenon, which affects infiltration as well as soil water retention and plant growth. Hydrophobicity can be responsible for enhanced surface runoff, erosion and preferential flow (VOGELMANN et al., 2013b). Due to this high relevance, a great number of studies have been conducted on possible causes of water repellency and the results point to a variety of factors causing and influencing soil water repellency (SCHAUMANN et al., 2007; DOERR et al., 2007).

Instituto de Ciências Biológicas, Fundação Universidade Federal do Rio Grande (FURG), 96170-000, São Lourenço do Sul, RS, Brasil. E-mail: eduardovogelmann@furg.br. Corresponding author.

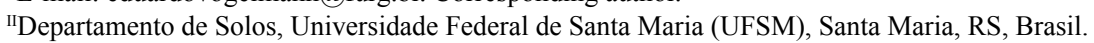

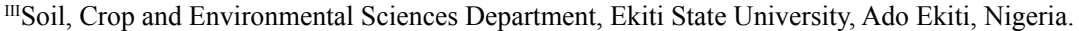
Received 01.15.14 Approved 07.11.14 Returned by the author 11.11.14 CR-2014-0042.R2 
Records of hydrophobic soils in Brazil are found mainly in areas cultivated with woody species and grasses (VOGELMANN et al., 2013a).

The occurrence of hydrophobicity is typically associated with the coating of soil particles by hydrophobic organic substances. These substances may be of various origins; most of them derived from local vegetation due to hydrophobic organic compounds in their chemical composition and are released either by deposition or decomposition of plant material (DOERR et al., 2007). Hydrophobicity is found to be related with other factors such as soil moisture (DOERR et al., 2007), pH (MATAIX-SOLERA et al., 2007), soil particle size (VOGELMANN et al. 2013b), incidence of fires (VOGELMANN et al., 2012), and presence of some fungi and bacteria species (SCHAUMANN et al., 2007).

The assessment of the hydrophobicity index has been a subject of research for decades. The method of water drop penetration time (WDPT), proposed by LETEY (1969), has been used to measure the persistence of water repellency in disaggregated soil samples (MATAIX-SOLERA et al., 2011). However, results have been inconsistent because of the varying degree of aggregate disruption. LEEDSHARRISON et al. (1994) proposed the tension micro-infiltrometer method, which measures the soil hydrophobicity index in macro aggregates with the advantage of being a measure of hydrophobicity of soil with little or no aggregate disruption.
Both methods have been commonly used in the evaluation of hydrophobic soils, however no studies have compared the accuracy and interrelationship of the results obtained by different methodologies. Therefore, the objective of this study was to compare the results of hydrophobicity index using the tension micro-infiltrometer method and water drop penetration time approach in eighteen different soil classes from southern Brazil.

\section{MATERIALS AND METHODS}

Description of study site and soil sample collection and analysis

A laboratory study was conducted during the summer of 2011 with soil samples from different soil classes from Rio Grande do Sul State, southern Brazil. Sampling sites had vegetation composed mainly of natural grassland with of vegetation on the occurrence of hydrophobicity. The main vegetation species at the sites sampled were Andropogonlateralis, Axonopusaffinis, Paspalum spp. and Aristidalaevis, which composed more than $80 \%$ of the vegetation in the sampled sites.

The soils of the area were classified according to the Brazilian System of Soil Classification (EMBRAPA, 2006) and the Soil Taxonomy developed by USDA (SOIL SURVEY STAFF, 2010) (Table 1). At each soil class, four undisturbed soil samples were collected at $0-5 \mathrm{~cm}$

Table 1 - Soil classification by the Soil Taxonomy (SOIL SURVEY STAFF, 2010) and Brazilian Soil Classification System (EMBRAPA, 2006) and textural class of the studied soils.

\begin{tabular}{|c|c|c|}
\hline Soil taxonomy & Brazilian soil classification system & Textural class \\
\hline Albaqualf1 & PlanossoloHáplicoEutrófico & Sandy clay loam \\
\hline Albaqualf2 & PlanossoloHáplicoEutrófico & Sandy loam \\
\hline Argiudoll & LuvissoloCrômicoPálico & Sandy clay loam \\
\hline Dystrudept1 & CambissoloHúmicoAlumínico & Clay \\
\hline Dystrudept2 & CambissoloHáplicoEutrófico & Silty clay \\
\hline Endoaqualf1 & GleissoloHáplicoDistrófico & Loam \\
\hline Endoaqualf2 & LuvissoloHáplicoÓrtico & Loam \\
\hline Haplohumult & ArgissoloVermelho-AmareloAlumínico & Clay loam \\
\hline Hapludalf & Argissolo Bruno-Acinzentado Alítico & Sandy loam \\
\hline Hapludert & VertissoloEbânicoÓrtico & Silty clay \\
\hline Hapludox1 & Latossolo Bruno Aluminoférrico & Clay \\
\hline Hapludox2 & LatossoloVermelhoDistrófico & Clay \\
\hline Hapludox3 & LatossoloVermelhoDistrófico & Clay \\
\hline Hapludox 4 & LatossoloVermelhoDistroférrico & Clay \\
\hline Kandiudox & NitossoloVermelhoDistroférrico & Clay \\
\hline Paleudalf1 & ArgissoloVermelhoDistrófico & Sandy loam \\
\hline Paleudalf2 & ArgissoloVermelhoDistrófico & Sandy loam \\
\hline Paleudult & ArgissoloVermelhoDistrófico & Clay loam \\
\hline
\end{tabular}


soil layer using core sampler of known volume. In the same point and same soil layer were collected disturbed and undisturbed soil samples (soil blocks) to the soil hydrophobicity analysis.

Granulometric composition was determined by the pipette method (GEE \& BAUDER, 1986), while soil organic carbon was determined using the NELSON \&SOMMERS (1996) method. Soil organic matter was obtained from soil organic carbon content by multiplying the latter by 1,724 , since it is assumed that organic carbon participates with $58 \%$ in the composition of soil organic matter (NELSON \& SOMMERS, 1996).

The bulk density was obtained using the paraffin clod method described by BLAKE\&HARTGE (1986). Soil particle density was determined following the method of GUBIANI et al. (2006). Total porosity $(f)$ was calculated using the equation 1 :

$$
f=\left(1-\frac{B d}{P d}\right) \times 100
$$

where: $B d$ is bulk density and $P d$ is particle density.

Tension micro-infiltrometer technique

The undisturbed soil samples were airdried in the laboratory until the point of brittleness. Subsequently, the aggregates were separated manually by means of traction, with respect to the cleavage surface, resulting in spheroidal-shape aggregates of about $20 \mathrm{~mm}$ in diameter. These aggregates were then subjected to soil sorptivity test using the tension micro-infiltrometer, with 15 repetitions for each soil.

This test consisted of an apparatus with a tube in which one end is connected to a reservoir with a liquid, either distilled water or ethanol $(95 \%$ $\mathrm{v} / \mathrm{v})$, and the other end has a small sponge $(4 \mathrm{~mm}$ of diameter) in contact with the aggregate for 2 minutes, and the cumulative mass of water or ethanol which infiltrates the soil by capillary is recorded as the difference in initial and final weight of the reservoir of liquid using an analytical scale with an accuracy of $0.001 \mathrm{~g}$. Hydraulic pressure differences which could affect flow within the column of fluid in the reservoir and the infiltrometer were eliminated. Error due to evaporative loss during the short testing time was reduced by applying a thin layer of silicone oil to the surface of the water reservoir. The two different liquids were employed during the sorptivity tests due to their different density, viscosity, and contact angle with the soil.

Water sorptivity test was first conducted on undisturbed aggregates, and afterward these soil aggregates were air-dried again and ethanol sorptivity test was performed on them.

The sorptivity (S) was obtained by equation 2 :

$$
S=\sqrt{\frac{Q f}{4 b r}}
$$

where: $Q$ corresponds to the measurement of liquid flow $\left(\mathrm{mm}^{3} \mathrm{~s}^{-1}\right) ; b$ is dependent on the parameter of the function of diffusion of water in the soil being taken as 0,$55 ; f$ is the total porosity $\left(\mathrm{mm}^{3} \mathrm{~mm}^{-3}\right) ; r$ is infiltrometer tip radius $(0.5 \mathrm{~mm}) . Q$ is obtained by the fluid infiltration rate in a circular area on the surface of the soil aggregate (LEEDS-HARRISON et al., 1994).

The hydrophobicity index or index of repellency ( $R$ ) was evaluated by comparing the values of water sorptivity and ethanol sorptivity using equation (3) as suggested by TILLMAN et al. (1989).

$$
S_{\text {water }}=\left[\frac{(\mu e / \gamma e)^{1 / 2}}{(\mu a / \gamma a)^{1 / 2}}\right] \mathrm{S}_{\text {ethanb }}
$$

where: $\mu e$ is the viscosity of ethanol $(95 \% \mathrm{v} / \mathrm{v})$ at $20^{\circ} \mathrm{C}\left(0.0012 \mathrm{~N} \mathrm{~s} \mathrm{~m}^{-2}\right)$; $\gamma e$ is the surface tension of ethanol $(95 \% \mathrm{v} / \mathrm{v})$ at $20^{\circ} \mathrm{C}\left(0.023 \mathrm{~N} \mathrm{~m}^{-1}\right) ; \mu a$ is the water viscosity at $20^{\circ} \mathrm{C}\left(0.0010 \mathrm{~N} \mathrm{~s} \mathrm{~m}^{-2}\right) ; \gamma a$ is the surface tension of water at $20^{\circ} \mathrm{C}\left(0.073 \mathrm{~N} \mathrm{~m}^{-1}\right)$.

Using these values, equation 3 is simplified into equation 4 (TILLMAN et al., 1989):

$$
\mathrm{S}_{\text {water }}=1.95 \mathrm{~S}_{\text {ethanol }}
$$

Thus, a further simplification of equation 4 by TILLMAN et al. (1989) yielded different values for different soils and were assigned the index, $\mathrm{R}$ as:

$$
\mathrm{R}=1.95\left[\frac{\mathrm{S}_{\text {ethanol }}}{\mathrm{S}_{\text {water }}}\right]
$$

Water drop penetration time (WDPT) test

The disturbed soil samples were air-dried, crushed and sieved through a 2-mm sieve. The soil samples were later placed in Petri dishes (volume of $25 \mathrm{~cm}^{3}$ ) for the test. The WDPT method consisted of applying three drops of water with a Pasteur pipette, and then measuring the time taken by the drops to penetrate the soil sample (KING, 1981). Each drop was released from a height of $10 \mathrm{~mm}$ above the soil surface to minimize the impact with the surface, with 15 repetitions for each soil.

Statistical analysis

The normal distribution of the experimental data was tested using the Shapiro-Wilk analysis. The WDPT data did not follow a normal distribution 
and were subjected to logarithmic transformation. All data were subjected to analysis of variance (ANOVA) at 5\% level of probability. When the F test was significant, means of hydrophobicity index and WDPT were compared by Tukey.

The following statistical performance indices were used to evaluate the degree of precision and accuracy of the estimates: index of Willmott " $d$ " (WILLMOTT et al., 1985) and correlation coefficient " $r$ ". The index " $d$ " indicates the degree of deviation of the estimated values with the values observed (0-1), being 0 for no agreement and 1 for perfect agreement, whereas the correlation coefficient " $r$ " determines the accuracy of each method and indicates the degree of dispersion of the points from the average.

\section{RESULTS AND DISCUSSION}

There was considerable variability in general soil properties and specifically in particle size distribution and soil organic matter content. The textural class of the soil series varied from sandy loam to clay (Table 2). The hydrophobicity was more severe in Albaqualf2, Dystrudept2 and Hapludert soils, which showed levels of organic matter of 18,41 and $56 \mathrm{~g} \mathrm{~kg}^{1}$, respectively, showing that the occurrence of hydrophobicity may be associated with a wide range of soil organic matter content.

By contrast, Argiudoll and Haplohumult soils did not show hydrophobicity even with high levels of organic matter (41 and $46 \mathrm{~g} \mathrm{~kg}^{-1}$, respectively). This indicates that the amount of organic material is not the only factor responsible for soil hydrophobicity, thus confirming the results already found by VOGELMANN et al. (2012) and MATAIX-SOLERA et al. (2007) which shows that hydrophobicity in the soil is due to the nature of organic compounds and not only on the amount of organic matter.

The hydrophobicity indices obtained using the two methods showed little variation, thus we can assume that both were potentially suitable for the analysis of the hydrophobic character of soils. There was little data dispersion around the line of the equation fitted to the observed data (Figure 1) as evidenced by the high coefficient of determination $\left(\mathrm{R}^{2}=0.87\right)$. This shows a satisfactory estimation of the hydrophobicity of the soil with allow coefficient of variation (Table 3 ). These values and coefficient of variation are in agreement with the values observed by LEEDS-HARRISSON et al. (1994) and VOGELMANN et al. (2012, 2013a).

Table 2 - Soil particle size distribution, bulk and particle density, total porosity, and soil organic matter content in the of $0-5 \mathrm{~cm}$ layer of the studied soils.

\begin{tabular}{|c|c|c|c|c|c|c|c|}
\hline \multirow{2}{*}{ Soil } & \multicolumn{3}{|c|}{---Granulometric composition $\left(\mathrm{g} \mathrm{kg}^{-1}\right)^{*---}$} & \multirow{2}{*}{$\begin{array}{l}\text { Bulk density } \\
\qquad\left(\mathrm{g} \mathrm{cm}^{-3}\right)\end{array}$} & \multirow{2}{*}{$\begin{array}{l}\text { Particle density } \\
\qquad\left(\mathrm{g} \mathrm{cm}^{-3}\right)\end{array}$} & \multirow{2}{*}{$\begin{array}{l}\text { Total porosity } \\
\left(\mathrm{cm}^{3} \mathrm{~cm}^{-3}\right)\end{array}$} & \multirow{2}{*}{$\begin{array}{l}\text { Organic matter } \\
\qquad\left(\mathrm{g} \mathrm{kg}^{-1}\right)\end{array}$} \\
\hline & Sand & Silt & Clay & & & & \\
\hline Albaqualf1 & 537 & 176 & 287 & 1.15 & 2.50 & 0,54 & 31 \\
\hline Albaqualf2 & 654 & 240 & 107 & 1,12 & 2,55 & 0,56 & 18 \\
\hline Argiudoll & 447 & 248 & 304 & 1,23 & 2,50 & 0,51 & 41 \\
\hline Dystrudept 1 & 295 & 268 & 438 & 1,08 & 2,54 & 0,57 & 30 \\
\hline Dystrudept2 & 113 & 441 & 446 & 1,21 & 2,55 & 0,53 & 41 \\
\hline Endoaqualf1 & 339 & 410 & 251 & 1,26 & 2,39 & 0,47 & 37 \\
\hline Endoaqualf2 & 396 & 474 & 130 & 1,17 & 2,40 & 0,51 & 25 \\
\hline Haplohumult & 245 & 490 & 265 & 1,29 & 2,46 & 0,48 & 46 \\
\hline Hapludalf & 665 & 196 & 139 & 1,14 & 2,51 & 0,55 & 24 \\
\hline Hapludert & 164 & 435 & 401 & 1,25 & 2,55 & 0,51 & 56 \\
\hline Hapludox 1 & 56 & 349 & 595 & 1,19 & 2,55 & 0,53 & 37 \\
\hline Hapludox2 & 393 & 191 & 416 & 1,15 & 2,52 & 0,54 & 27 \\
\hline Hapludox3 & 430 & 168 & 403 & 1,21 & 2,57 & 0,53 & 28 \\
\hline Hapludox4 & 42 & 338 & 620 & 1,10 & 2,55 & 0,57 & 35 \\
\hline Kandiudox & 307 & 196 & 497 & 1,25 & 2,48 & 0,49 & 26 \\
\hline Paleudalf1 & 643 & 253 & 100 & 1,03 & 2,49 & 0,60 & 27 \\
\hline Paleudalf2 & 592 & 237 & 170 & 1,11 & 2,56 & 0,57 & 13 \\
\hline Paleudult & 395 & 337 & 269 & 1,25 & 2,55 & 0,51 & 21 \\
\hline
\end{tabular}

*sand $=2-0,05 \mathrm{~mm} ;$ silt $=0,002-0,05 \mathrm{~mm} ;$ clay $=<0,002 \mathrm{~mm}$. 
Table 3 - Values of water and ethanol sorptivity, hydrophobicity index and water drop penetration time (WDPT) in the soil layer of 0-5cm of the studied soils.

\begin{tabular}{|c|c|c|c|c|c|c|c|c|c|c|}
\hline \multirow{3}{*}{$\begin{array}{l}\text { Soil } \\
\text { Albaqualf1 }\end{array}$} & \multicolumn{2}{|c|}{ Water sorptivity } & \multicolumn{2}{|c|}{ Ethanol sorptivity } & \multirow{2}{*}{\multicolumn{3}{|c|}{ Hydrophobicity index }} & \multicolumn{3}{|c|}{ WDPT } \\
\hline & \multicolumn{4}{|c|}{ 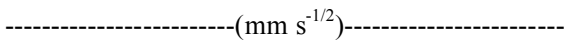 } & & & & \multicolumn{3}{|c|}{ - } \\
\hline & 0.043 & $\pm 0,005^{*}$ & 0,088 & $\pm 0,010$ & 4,0 & $\mathrm{c}$ & $\pm 0,4$ & 46 & $\mathrm{~d}$ & $\pm 3,0$ \\
\hline Albaqualf2 & $0 ., 034$ & $\pm 0,005$ & 0,152 & $\pm 0,023$ & 8,7 & $b$ & $\pm 0,6$ & 180 & $\mathrm{c}$ & \pm 25 \\
\hline Argiudoll & 0,015 & $\pm 0,002$ & 0,016 & $\pm 0,002$ & 2,1 & ef & $\pm 0,3$ & 2 & $\mathrm{f}$ & $\pm 0,5$ \\
\hline Dystrudept 1 & 0,049 & $\pm 0,005$ & 0,053 & $\pm 0,006$ & 2,1 & ef & $\pm 0,2$ & 2 & $\mathrm{f}$ & $\pm 0,4$ \\
\hline Dystrudept 2 & 0,013 & $\pm 0,002$ & 0,060 & $\pm 0,008$ & 9,0 & $\mathrm{~b}$ & $\pm 0,8$ & 235 & $\mathrm{~b}$ & \pm 20 \\
\hline Endoaqualf1 & 0,053 & $\pm 0,007$ & 0,087 & $\pm 0,011$ & 3,2 & d & $\pm 0,4$ & 23 & e & $\pm 2,5$ \\
\hline Endoaqualf2 & 0,077 & $\pm 0,008$ & 0,051 & $\pm 0,006$ & 1,3 & $\mathrm{f}$ & $\pm 0,1$ & 2 & $\mathrm{f}$ & $\pm 0,2$ \\
\hline Haplohumult & 0,077 & $\pm 0,012$ & 0,067 & $\pm 0,010$ & 1,7 & $\mathrm{f}$ & $\pm 0,2$ & 2 & $\mathrm{f}$ & $\pm 0,2$ \\
\hline Hapludalf & 0,054 & $\pm 0,007$ & 0,063 & $\pm 0,008$ & 2,3 & ef & $\pm 0,3$ & 3 & $\mathrm{f}$ & $\pm 0,3$ \\
\hline Hapludert & 0,009 & $\pm 0,001$ & 0,050 & $\pm 0,007$ & 10,9 & $\mathrm{a}$ & $\pm 0,9$ & 800 & $\mathrm{a}$ & \pm 54 \\
\hline Hapludox1 & 0,088 & $\pm 0,011$ & 0,122 & $\pm 0,016$ & 2,7 & $\mathrm{de}$ & $\pm 0,3$ & 3 & $\mathrm{f}$ & $\pm 0,2$ \\
\hline Hapludox2 & 0,042 & $\pm 0,005$ & 0,034 & $\pm 0,004$ & 1,6 & $\mathrm{f}$ & $\pm 0,2$ & 2 & $\mathrm{f}$ & $\pm 0,1$ \\
\hline Hapludox3 & 0,055 & $\pm 0,006$ & 0,085 & $\pm 0,009$ & 3,0 & $\mathrm{~d}$ & $\pm 0,3$ & 24 & e & $\pm 5,0$ \\
\hline Hapludox4 & 0,074 & $\pm 0,011$ & 0,053 & $\pm 0,008$ & 1,4 & $\mathrm{f}$ & $\pm 0,2$ & 2 & $\mathrm{f}$ & $\pm 0,4$ \\
\hline Kandiudox & 0,052 & $\pm 0,007$ & 0,059 & $\pm 0,008$ & 2,2 & ef & $\pm 0,3$ & 1 & $\mathrm{f}$ & $\pm 0,2$ \\
\hline Paleudalf1 & 0,087 & $\pm 0,011$ & 0,067 & $\pm 0,009$ & 1,5 & $\mathrm{f}$ & $\pm 0,2$ & 2 & $\mathrm{f}$ & $\pm 0,4$ \\
\hline Paleudalf2 & 0,034 & $\pm 0,005$ & 0,035 & $\pm 0,005$ & 2,0 & ef & $\pm 0,2$ & 1 & $\mathrm{f}$ & $\pm 0,1$ \\
\hline Paleudult & 0,068 & $\pm 0,009$ & 0,101 & $\pm 0,013$ & 2,9 & $\mathrm{~d}$ & $\pm 0,3$ & 4 & $\mathrm{f}$ & $\pm 0,2$ \\
\hline C.v. & & & & & 12,7 & & & 9,3 & & \\
\hline
\end{tabular}

Values with the same letters are not statistically difference at $\mathrm{P}<0.05$ significant level. C.v.-coefficient of variation. $*$ Standard deviation.

The lower coefficient of variation obtained by the method WDPT could be due to the fact that the soil samples were disturbed, that is, ground and sieved, so there may be a uniformity of hydrophobic compounds when present in the soil matrix. CERDÁ \& DOERR (2008) described that the disintegration of the soil will expose internal areas of aggregates, thereby exposing areas that are not hydrophobic such as in the case of soils that were sieved and homogenized, which could result into reduction in hydrophobicity. VOGELMANN et al. (2012) reported that the compounds may accumulate on the outer surface of macroaggregates or in smaller clusters, which may experience a reduction in its concentration internally. Thus, the hydrophobicity is not uniformly distributed in the soil matrix. Hydrophobicity may be reduced by homogenizing the distribution of these compounds in the soil matrix.

In the tension of the micro-infiltrometer method, the samples experienced less disruption due to the use of macroaggregates. This treatment preserved the natural distribution of compounds in the soil matrix (LEEDS-HARRISON et al., 1994). Thus, the homogenization of hydrophobic compounds in the soil matrix in the WDPT method may be responsible for the lower coefficient of variation obtained, as also observed by CERDÁ \& DOERR (2008).

Moreover, it is noteworthy that the WDPT method does not consider all the original physical or hydraulic properties of soil which can restrict or favor the infiltration of water into the soil, like soil porosity and physical properties of liquids as is the case of viscosity and surface tension. However, these liquid properties are considered when using the tension micro-infiltrometer technique, as shown in equations 2 and 3. Failure of using such parameters may result in erroneous inference, for example, a soil with low porosity where water droplets do not infiltrate due to the small pore volume that restricts and decreases infiltration into the soil may be interpreted as a hydrophobic soil from the point of view of the WDPT method.

The index "d" of WILLMOTT et al. (1985), which reflects the accuracy of the method, indicated an "average" performance (0.57). As this index is a mathematical approximation in evaluating the correctness and dispersion of the values, it is evident that the results obtained by both methods show good 


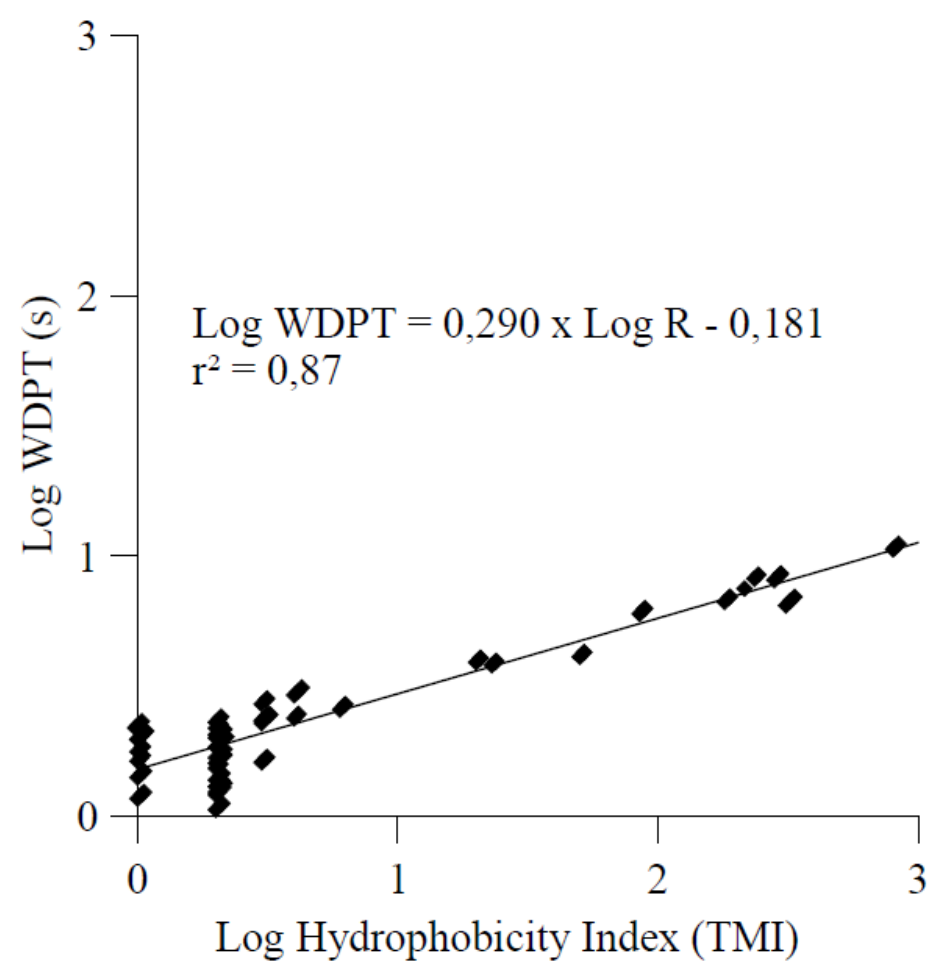

Figure 1 - Relationship between the hydrophobicity index (R) determined by the method of tension micro-infiltrometer(TMI) and water drop penetration time (WDPT).

correlation between the results and a small scattering of data as shown in figure 1 . The determination of soil hydrophobicity by both methods exhibited deviation when compared to each other, with high magnitude when either log hydrophobicity index or log WDPT is less than 1. This indicates a possible divergence in determining the degree of hydrophobicity in less hydrophobic soils. In contrast, for soils with high hydrophobicity degree, both methods gave greater similarity in the magnitudes of evaluation.

\section{CONCLUSION}

The methods of soil hydrophobicity determination through the use of tension microinfiltrometer and the droplet penetration time (WDPT) gave low coefficients of variation and good correlation between the results, hence both were considered effective in evaluating soil hydrophobicity, especially when the log hydrophobicity index or log WDPT is $>1$. As a result of the homogeneity of the soil samples, the WDPT method may provide lower coefficients of variation because of the homogeneous distribution of hydrophobic compounds, in contrast to the tension micro-infiltrometer technique where the soil structure is preserved.

\section{REFERENCES}

BLAKE, G.R.; HARTGE, K.H. Bulk density. In: KLUTE, A. Methods of soil analysis, part1: physical and mineralogical methods. Madison: SSSA Publishing, 1986. p.363-375.

CERDÀ, A. DOERR, S.H. The effect of ash and needle cover on surface runoff and erosion in the immediate post-fire period. Catena, v.74, p.256-263, 2008. Available from: <http://dx.doi. org/10.1016/j.catena.2008.03.010>. Accessed: Dec. 20, 2013. doi: 10.1002/hyp.6762.

DOERR, S.H. et al. Water repellence of soils: new insights and emerging research needs. Hydrological Processes, v.21, p.22232228, 2007. Available from: <http://onlinelibrary.wiley.com/ doi/10.1002/hyp.6762/abstract $>$. Accessed: Dec. 20, 2013. doi: 10.1002/hyp.6762.

EMPRESA BRASILEIRA DE PESQUISA AGROPECUÁRIA (EMBRAPA). Centro Nacional de Pesquisa de Solos. Sistema brasileiro de classificação de solos. 2.ed. Rio de Janeiro, 2006. 306p. 
GEE, G.W.; BAUDER, J.W. Particle size Analysis. In: KLUTE, A. Methods of soil analysis, part1: physical and mineralogical methods. Madison: SSSA Publishing, 1986. p.383-411.

GUBIANI, P.I. et al. Método alternativo para a determinação da densidade de partículas do solo - exatidão, precisão e tempo de processamento. Ciência Rural, v.36, p.664-668, 2006. Available from: $<$ http://www.scielo.br/scielo.php?script $=$ sci_arttext\&p id=S0103-84782006000200049>. Accessed: Dec. 20, 2013. doi: $10.1590 / \mathrm{S} 0103-84782006000200049$.

KING, P.M. Comparison of methods for measuring severity of water repellence of sandy soils and assessment of some factors that affect its measurement. Australian Journal of Soil Research, v.19, p.275-285, 1981 .

LEEDS-HARRISON, P.B. et al. A device for determining the sorptivity of soil aggregates. European Journal of Soil Science, v.45, p.269-272, 1994

LETEY, J. Measurement of contact angle, water drop penetration time, and critical surface tension. In: BANO, L.F. de; LETEY, J. Proceedings of Symposium on water-repellent soils. Riverside: University of California, 1969. p.43-47.

MATAIX-SOLERA, J. et al. Longevity of soil water repellency in a former wastewater disposal tree stand and potential amelioration. Geoderma, v.165, p.78-83, 2011. Available from: <http://www. sciencedirect.com/science/article/pii/S0016706111001959>. Accessed: Dec. 14,2013. doi: 10.1016/j.geoderma.2011.07.006.

MATAIX-SOLERA, J. et al. Water repellency under different plant species in a calcareous forest soil in a semiarid Mediterranean environment. Hydrological Processes, v.21, p.2300-2309, 2007. Available from: <http://onlinelibrary.wiley.com/doi/10.1002/ hyp.6750/abstract>. Accessed: Dec.14, 2013. doi: 10.1002/hyp.6750.

NELSON, D.W.; SOMMERS, L.E. Total carbon, organic carbon and organic matter. In: SPARKS, D.L. Methods of soil analysis: chemical methods. Part 3.Madison: SSSA Publishing, 1996. p.61-1010.

SCHAUMANN, G.E. et al. Influence of biofilms on the water repellency of urban soil samples. Hydrology Processes, v.21, p.2276-2284, 2007. Available from: <http://onlinelibrary.wiley. com/doi/10.1002/hyp.6746/abstract>. Accessed: Dec. 17, 2013. doi: 10.1002/hyp.6746.

SOIL SURVEY STAFF. Keys to soil taxonomy. 11.ed. Washington DC: USDA-Natural Resources Conservation Service, 2010. 372p.

TILLMAN, R.W. et al. Water repellency and its measurement using intrinsic sorptivity. Australian Journal of Soil Research, v.27, p.637-644, 1989.

VOGELMANN, E.S. et al. Can occurrence of soil hydrophobicity promote the increase of aggregates stability? Catena, v.110, p.24-31, 2013a. Available from: <http://www.sciencedirect.com/ science/article/pii/S0341816213001483>. Accessed: Dec. 20, 2013. doi: 10.1016/j.catena.2013.06.009.

VOGELMANN, E.S. et al. Hydro-physical processes and soil properties correlated with origin of soil hydrophobicity. Ciência Rural, v.43, p.1582-1589, 2013b. Available from: <http:// www.scielo.br/scielo.php?script $=$ sci_arttext\&pid $=$ S0 103 84782013000900008\&lng=en\&nrm=iso $>$. Accessed: Dec. 20, 2013. doi: 10.1590/S0103-84782013005000107.

VOGELMANN, E.S. et al. Soil hydro-physical changes in natural grassland of southern Brazil subjected to burning management. Soil Research, v.50, p.465-472, 2012. Available from: <http://www. publish.csiro.au/paper/SR12106.htm>. Accessed: Dec. 19, 2013. doi:10.1071/SR12106.

WILLMOTT, C.J. et al. Statistics for the evaluation and comparison of models. Journal of Geophysical Research, v.90, p.8995-9005, 1985. 